\title{
Wheat Stripe Rust Epidemics and Races of Puccinia striiformis f. sp. tritici in the United States in 2000
}

Xianming Chen, USDA-ARS, Wheat Genetics, Physiology, Quality, and Disease Research Unit, and Department of Plant Pathology, Washington State University, Pullman 99164-6430; Mary Moore, Department of Plant Pathology, Washington State University; Eugene A. Milus, Department of Plant Pathology, University of Arkansas, Fayetteville 72701; David L. Long, USDA-ARS, Cereal Disease Laboratory, University of Minnesota, St. Paul 55108-1050; Roland F. Line, Department of Plant Pathology, Washington State University; David Marshall, Research and Extension Center, Texas A\&M University, Dallas 75252-6599; and Lee Jackson, Department of Agronomy and Range Sciences, University of California, Davis 95616-8515

\begin{abstract}
Chen, X. M., Moore, M., Milus, E. A., Long, D. L., Line, R. F., Marshall, D., and Jackson, L. 2002. Wheat stripe rust epidemics and races of Puccinia striiformis f. sp. tritici in the United States in 2000. Plant Dis. 86:39-46.

Wheat stripe rust, caused by Puccinia striiformis f. sp. tritici, is most destructive in the western United States and has become increasingly important in the south-central states. The disease has been monitored by collaborators through field surveys and in disease nurseries throughout the United States. In the year 2000, stripe rust occurred in more than 20 states throughout the country, which was the most widespread occurrence in recorded history. Although fungicide applications in many states reduced yield losses, the disease caused multimillion dollar losses in the United States, especially in Arkansas and California. One of the prevalent cultivars, RSI 5, had a yield loss of about 50\% in the Sacramento-San Joaquin Delta region of California. In the Pacific Northwest, wheat losses due to stripe rust were minimal because cultivars with durable resistance were widely grown and the weather in May 2000 was not favorable for the disease. To identify races of the pathogen, stripe rust collections from 20 states across the United States were analyzed on 20 wheat differential cultivars, including Clement $(\mathrm{Yr} 9, \mathrm{YrCle})$, Compair ( $Y r 8, \operatorname{Yr} 19)$, and the $\operatorname{Yr} 8$ and $Y r 9$ near-isogenic lines. In 2000, 21 previously identified races and 21 new races were identified. Of the 21 new races, 8 were pathotypes with combinations of virulences previously known to exist in the United States, and 13 had virulences to one or more of the lines $\operatorname{Yr} 8, \operatorname{Yr} 9$, Clement, or Compair. This is the first report of virulence to $\operatorname{Yr} 8$ and $\operatorname{Yr} 9$ in the United States. Most of the new races were also virulent on Express. Races that are virulent on Express have been identified in California since 1998. The races virulent on $\operatorname{Yr} 8, \operatorname{Yr} 9$, and Express were widely distributed in California and states east of the Rocky Mountains in 2000. The epidemic in 2000 demonstrates that increased efforts to breed for stripe rust resistance are needed in California, the south-central states, and some other states in the Great Plains. Diversification of resistance genes and use of durable resistance should prevent large-scale and severe epidemics.
\end{abstract}

Additional keywords: Triticum aestivum, yellow rust

Stripe rust, caused by Puccinia striiformis Westend. f. sp. tritici Eriksson, is an important wheat disease worldwide. In the United States, stripe rust occurs most frequently in the western states and has become increasingly important in the south-central states and the Great Plains.

Corresponding author: X. M. Chen

E-mail: xianming@mail.wsu.edu

PPNS 0325, College of Agriculture and Home Economics Research Center, Washington State University, Pullman, WA 99164.

Accepted for publication 26 September 2001.

Publication no. D-2001-1112-01R

This article is in the public domain and not copyrightable. It may be freely reprinted with customary crediting of the source. The American Phytopathological Society, 2002. fornia and the Pacific Northwest $(49,53)$. These devastating epidemics led to an increased emphasis on breeding for resistance to stripe rust. Since the 1960 s, stripe rust has been monitored in the United States, especially in the western states. Races of $P$. striiformis f. sp. tritici have been characterized with a set of differential cultivars $(35,36)$

Before 2000, 59 CDL (Cereal Disease Laboratory at Pullman, WA) races of $P$. striiformis $\mathrm{f}$. sp. tritici had been named in the United States (35; R. F. Line and X. M. Chen, unpublished data). All these races were first identified and distributed in the western United States. Only two races, CDL-3 (virulent on wheat cvs. Lemhi and Heines VII) and CDL-8 (virulent on Lemhi, Heines VII, and Yamhill), had been detected in the areas east of the Rocky Mountains before 1997. In 1997 through 1999, two other races, CDL-22 (virulent on Lemhi, Heines VII, and Fielder) and CDL26 (virulent on Lemhi, Heines VII, Yamhill, and Fielder) were detected east of the Rocky Mountains. In California, 13 races had been detected prior to 2000 (35; R. F. Line and X. M. Chen, unpublished data), including races CDL-58 (virulent on Lemhi, Lee, Fielder, and Express) and CDL-59 (virulent on Lemhi, Heines VII, Lee, Fielder, and Express). Until 2000, races that infected the seedlings of 'Express' had been detected only in California. Among the 59 races identified before 2000 in the United States, 55 had been detected in the Pacific Northwest (35; R. F. Line and X. M. Chen, unpublished data).

In the Pacific Northwest, environmental conditions favorable for stripe rust occur every year in western Washington and in irrigated fields, and in 3 out of every 4 years in other areas of the Pacific Northwest and nonirrigated fields. In the southcentral United States, favorable environments occur less frequently. In addition to favorable environmental conditions, susceptible cultivars are required for stripe rust epidemics. Many races detected in the United States caused major epidemics because they are virulent on cultivars that were resistant to all previous prevalent races $(34,36)$. 
The objectives of this article are to document the distribution and severity of stripe rust in the United States and associated yield losses, to identify races of the pathogen, and to discuss the causes of the 2000 epidemic and strategies for future management of stripe rust in the United States.

\section{MATERIALS AND METHODS}

Stripe rust monitoring. Stripe rust was monitored in disease nurseries, breeding nurseries, and commercial fields across the United States. Trap plots for monitoring wheat stripe rust were planted in the $\mathrm{Pa}$ cific Northwest and California. Cultivar, growth stage, rust prevalence (percentage of plants infected), and rust severity (percentage of leaf area infected) were recorded whenever possible. Samples of stripe rust-infected leaves were collected and sent to the United States Department of Agriculture-Agricultural Research Service (USDA-ARS) Laboratory of the Wheat Genetics, Physiology, Quality, and Disease Research Unit at Pullman, WA for

Evaluating rust samples for virulence. Races of $P$. striiformis $\mathrm{f}$. sp. tritici were identified using the methods described by Line and Qayoum (36). Sixteen wheat cultivars that have been previously used to differentiate North American races of $P$. striiformis f. sp. tritici were used (Table 1). The $\operatorname{Yr} 8$ and $\operatorname{Yr} 9$ near-isogenic lines (in the 'Avocet Susceptible' background), 'Clement' ( $\mathrm{Yr} 9$ and $\mathrm{YrCle}$ ), and 'Compare' ( $\mathrm{Yr} 8$ and $Y r 19)$ also were used as differentials. The $\operatorname{Yr} 8$ and $\operatorname{Yr} 9$ lines were developed in the Plant Breeding Institute at the University of Sydney and provided by Dr. Colin $\mathrm{R}$. Wellings. Wheat seeds were planted in a potting mixture of 24 liters of peat moss, 8 race identification.

liters of perlite, 12 liters of sand, 12 liters of commercial potting soil, 16 liters of vermiculite, and $250 \mathrm{~g}$ of 14-14-14 Osmacote, and grown in a rust-free greenhouse.

Urediniospores from the collected samples were transferred to seedlings at the two-leaf stage of the susceptible wheat cvs. Nugaines or Michigan Amber for spore increase. Inoculated plants were kept in a dew chamber at $10^{\circ} \mathrm{C}$ for $24 \mathrm{~h}$ and then placed in a growth chamber programmed to change temperature gradually between a minimum of 2 to $5^{\circ} \mathrm{C}$ at 2:00 A.M. during the 8 -h dark period and a maximum of 18 to $20^{\circ} \mathrm{C}$ at 2:00 P.M. during the 16 -h light period. Metal halide lights were used to supplement the natural daylight and to extend the photoperiod to $16 \mathrm{~h}$. Inoculated plants were isolated by plastic booths to prevent cross contamination. Urediniospores were collected using a vacuum spore collector and were used to inoculate seedlings of the wheat cultivars that are used to differentiate North American races of $P$. striiformis f. sp. tritici. If the spores from a collection showed a mixture of races on the 20 differential cultivars, the spores were inoculated on key differential cultivars, and the races separated during incubation to obtain subisolates. A subisolate was tested again on the 20 differential cultivars to confirm the virulence pattern. The isolation process was often repeated several times to obtain pure isolates for race designation. For new races, single-pustule isolations also were used. Tests for all isolates were repeated, except for a few isolates that were pure and clearly resembled previously characterized races in the initial tests.

Data on infection types (IT), based on a 0 -to-9 scale (36), were recorded at 20 to 22 days after inoculation. Two or more sets of

Table 1. Wheat cultivars used to differentiate races of Puccinia striiformis f. sp. tritici

\begin{tabular}{|c|c|c|c|c|}
\hline \multicolumn{2}{|c|}{ Differential } & \multicolumn{2}{|c|}{ Cultivar } & \multirow[b]{2}{*}{$Y r$ gene $^{b}$} \\
\hline Number & Name & ID number ${ }^{\mathrm{a}}$ & Type & \\
\hline 1 & Lemhi & CI 011415 & Spring & $\operatorname{Yr} 21$ \\
\hline 2 & Chinese 166 & CI 011765 & Winter & Yrl \\
\hline 3 & Heines VII & PI 201195 & Winter & $Y r 2, Y r H V I I$ \\
\hline 4 & Moro & CI 013740 & Winter & Yr10, YrMor \\
\hline 5 & Paha & CI 014485 & Winter & YrPa1, $Y r P a 2, Y r P a 3$ \\
\hline 6 & Druchamp & CI 013723 & Winter & Yr3a, YrD, YrDru \\
\hline 7 & Riebesel 47/51 & PI 295999 & Winter & $\operatorname{Yr} 9,+$ \\
\hline 8 & Produra & CI 017460 & Spring & $\operatorname{YrPr} 1, \operatorname{YrPr} 2$ \\
\hline 9 & Yamhill & CI 014563 & Winter & Yr2, Yr4a, YrYam \\
\hline 10 & Stephens & CI 017596 & Winter & Yr3a, YrS, YrSte \\
\hline 11 & Lee & CI 012488 & Spring & $Y r 7, Y r 22, Y r 23$ \\
\hline 12 & Fielder & CI 017268 & Spring & Yr6, Yr20 \\
\hline 13 & Tyee & CI 017773 & Winter & YrTye \\
\hline 14 & Tres & CI 017917 & Winter & $\operatorname{YrTr} 1, Y r T r 2$ \\
\hline 15 & Hyak & PI 511674 & Winter & Yr17 \\
\hline 16 & Express & DA 984034 & Spring & Unknown \\
\hline 17 & Yr8 & YR 000008 & Spring & $Y r 8$ \\
\hline 18 & Yr9 & YR 000009 & Spring & $\operatorname{Yr} 9$ \\
\hline 19 & Clement & PI 518799 & Winter & Yr9, YrCle \\
\hline 20 & Compair & PI 325842 & Spring & $\operatorname{Yr} 8, \operatorname{Yr} 19$ \\
\hline
\end{tabular}

${ }^{\mathrm{a}} \mathrm{CI}=$ Crop Index number, PI $=$ Plant Identification number, and $\mathrm{YR}=$ Yellow Rust resistance gene line number.

${ }^{\mathrm{b}}$ Chen and Line (9-12), Chen et al. $(8,15,16)$, and McIntosh et al. (40). data on infection types were summarized and converted to avirulence/virulence data. An isolate was considered avirulent on a specific differential cultivar when there were no symptoms (IT 0) or there were necrotic or chlorotic flecks (IT 1), necrotic or chlorotic blotches without sporulation (IT 2), or necrotic or chlorotic blotches with only a trace of to slight sporulation (IT 3 to 4). An isolate was considered to be virulent if it caused moderate to abundant sporulation, with or without chlorosis or necrosis (IT 5, 6, 7, 8, or 9).

\section{RESULTS}

Distribution of wheat stripe rust in the United States. In 2000, wheat stripe rust was reported in 25 states (Fig. 1). This was the most widespread distribution of stripe rust in the United States in recorded history.

South-central states. In 2000, wheat stripe rust was first reported in southern Louisiana in early March. As the growing season progressed, stripe rust was found in Arkansas, Texas, northern Louisiana, southern Oklahoma, northern Alabama, and west-central Mississippi. Stripe rust was light in northern Alabama and westcentral Mississippi because of the dry weather in late April. The disease was severe in commercial fields throughout northeastern Texas, northwestern Louisiana, southern Oklahoma, and northeastern Arkansas. Entire fields were yellow from top to bottom, and many fields were sprayed with a fungicide to control the disease. In northwestern Arkansas plots, $50 \%$ of the wheat entries were either destroyed or severely damaged by stripe rust.

Central and north-central states. Wheat stripe rust occurred throughout Kansas, South Dakota, northwestern Missouri, southeastern Nebraska, central Indiana, Minnesota, southeastern North Dakota, northeastern Colorado, northeastern Montana, and from central Illinois to southwestern Michigan. In most of these regions, stripe rust severity ranged from a trace to $20 \%$. In south-central Kansas, stripe rust was severe (up to $60 \%$ severity) on a few of the hard red winter cultivars, especially those with the $1 \mathrm{~B} / 1 \mathrm{R}$ chromosomal translocation. In central Indiana, stripe rust was light in commercial fields and was more severe in breeding nurseries. In central and eastern South Dakota, stripe rust was widespread on winter wheat and some winter wheat plots at Brookings had high levels of infection (e.g.; $80 \%$ on 'Siouxland'). Traces of stripe rust were also found in spring wheat fields and nursery plots in South Dakota. Severity levels of $50 \%$ were observed in irrigated plots in northeastern Montana.

Eastern states. In early May, wheat stripe rust was found in a southern and northwest Georgia. In mid-May, traces of stripe rust were found in plots at Blacksburg, Virginia. These were the first reports 
of wheat stripe rust east of the Appalachian Mountains in these states.

California. Wheat stripe rust was severe in the Sacramento Valley and SacramentoSan Joaquin Delta, particularly on cv. RSI 5 , which was grown on 84,000 acres in 2000. On 400 acres of one farm in the Sacramento-San Joaquin Delta, there was $100 \%$ severity and $100 \%$ incidence of stripe rust at soft dough stage. High severity levels of wheat stripe rust were observed in nurseries in the San Joaquin Valley. Cool temperatures and several storm systems in mid-May provided moisture that allowed stripe rust to increase on wheat in California's Central Valley. Cool spring weather also allowed wheat stripe rust to increase in commercial fields of several cultivars in the central and southern portions of the San Joaquin Valley. Severity levels of $100 \%$ were observed on breeding lines and cultivars in that area.

Pacific Northwest. Throughout the spring, wheat stripe rust increased in research plots and commercial fields in western Washington. Later in the growing season, stripe rust severity was over $90 \%$ on susceptible wheat entries in experimental plots in western Washington. In eastern Washington and northern Idaho, stripe rust was prevalent, but development was slower than normal because of the dry conditions in early and mid-May that were not conducive for rust development. Stripe rust losses were minimal because most of the cultivars have high-temperature, adultplant resistance.

Wheat yield losses to stripe rust. A loss of over nine million bushels of wheat was estimated for the eight states that had significant epidemics of wheat stripe rust in 2000 (Table 2). Even though over 300,000 acres (about one-third of total acreage) of wheat were sprayed with fungicides to control stripe rust, Arkansas suffered the highest yield loss. In California, RSI 5, one of the prevalent wheat cultivars, suffered about $50 \%$ yield loss in some areas, particularly in the Sacramento-San Joaquin Delta region. Fourteen other states (Alabama, Colorado, Georgia, Idaho, Illinois, Indiana, Michigan, Mississippi, Missouri, Nebraska, Ohio, Oregon, South Dakota, and Virginia) observed stripe rust, but did not estimate yield losses because yield losses in these states were considered not significant.

Identification of races of $\boldsymbol{P}$. striiformis f. sp. tritici. A total of 173 collections of wheat stripe rust were obtained from 20 states (Table 3). Viable spores were recovered from 159 of the samples and were tested on the 20 wheat differential cultivars. Most of the original collections appeared to be mixtures of different races in the initial tests; therefore, subcultures from individual differential cultivars were obtained and tested on the whole set of differentials.

From the original and subcultures, 21 previously existing races and 21 new races were identified (Table 4). In this article, all previously identified and new races are designated as PST races for P. striiformis $\mathrm{f}$. sp. tritici, instead of as CDL (after the now-defunct USDA-ARS Cereal Disease Laboratory at Pullman, WA) races used in the past. The PST designations were more descriptive and coincided with the PSH designation for races of $P$. striiformis $\mathrm{f}$. $\mathrm{sp}$. hordei that cause barley stripe rust (18). All old races will keep the same numbers.
Virulence patterns of old races were not changed by adding Clement, Compair, and the $\operatorname{Yr} 8$ and $\operatorname{Yr} 9$ near-isogenic lines, which were confirmed by the germ plasm tests with prevalent races and genetic studies with selected races in the past several years $(10,11,15,16)$, and by testing isolates of selected old races on the new differentials in 2000 (X. M. Chen and R. F. Line, unpublished data). Based on virulence on the differentials, Express, and the $\mathrm{Yr} 9$ and $\mathrm{Yr} 8$ near-isogenic lines, the new races can be grouped into races virulent on Express versus races avirulent on Express, and races virulent on $\operatorname{Yr} 9, \operatorname{Yr} 8$, or both versus races avirulent on $\operatorname{Yr} 9, \operatorname{Yr} 8$, or both.

Races with virulence and avirulence on Express. Races PST-58 (virulent on Lemhi, Lee, Fielder, and Express) and PST-59 (virulent on Lemhi, Heines VII, Lee, Fielder, and Express) were first

Table 2. Estimated yield losses of wheat due to stripe rust (Puccinia striiformis f. sp. tritici) in 2000

\begin{tabular}{lcc}
\hline & \multicolumn{2}{c}{ Yield loss } \\
\cline { 2 - 3 } State & Percentage & $\mathbf{1 , 0 0 0}$ bushels \\
\hline Arkansas & 7.0 & $4,519.6$ \\
California & 3.0 & 757.7 \\
Kansas & 0.05 & 179.2 \\
Louisiana & 0.5 & 49.5 \\
Oklahoma & 1.0 & $1,472.2$ \\
Oregon & 1.5 & 88.2 \\
Texas & 0.5 & 335.0 \\
Washington & 1.0 & $1,667.1$ \\
Total & $0.43^{\mathrm{a}}$ & $9,068.5$ \\
\hline
\end{tabular}

a Percentage of total yield loss of wheat in the United States was calculated based on the U.S. total production of $2,123,735,000$ bushels.

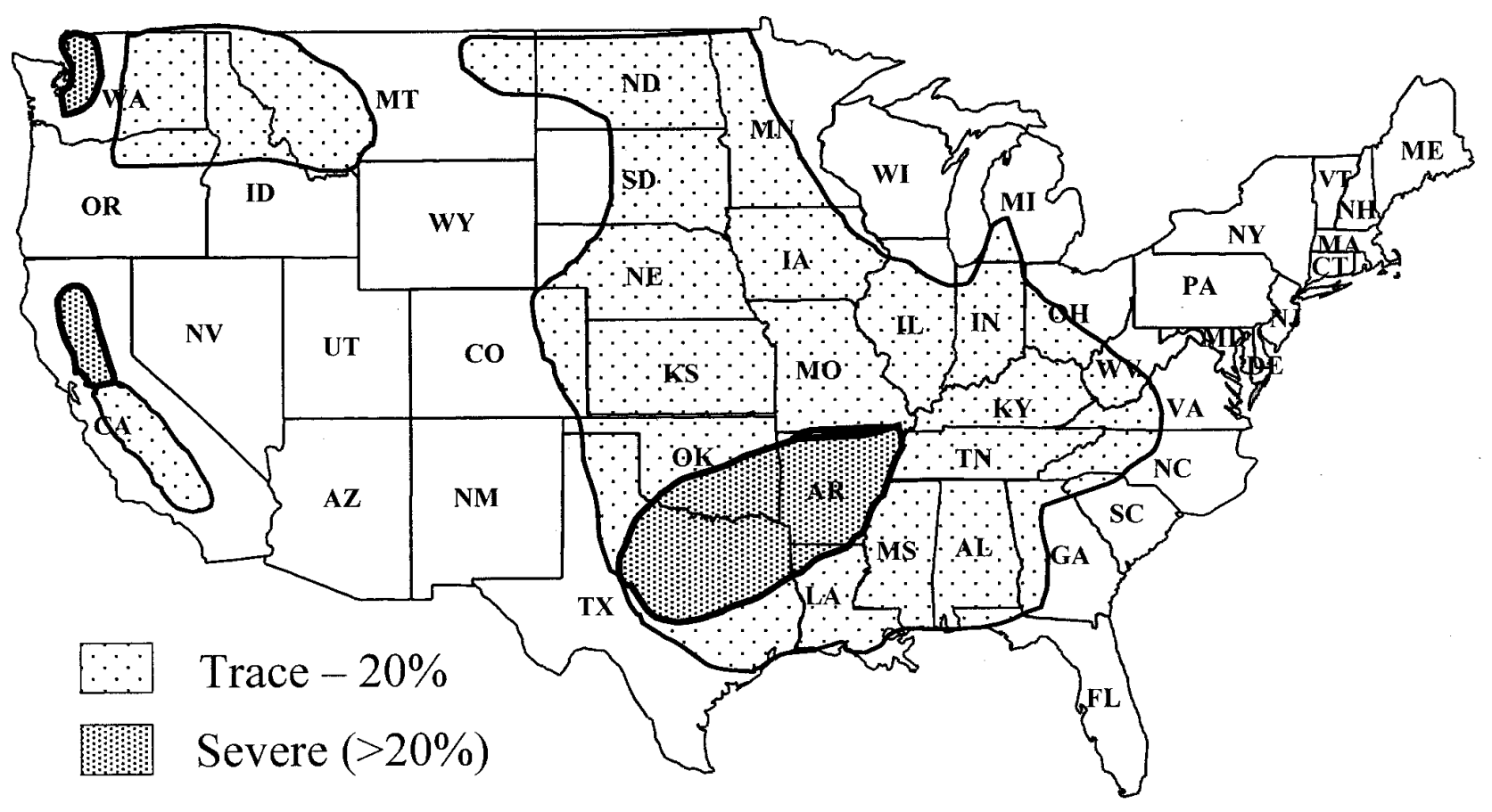

Fig. 1. Occurrence and disease severity of wheat stripe rust caused by Puccinia striiformis f. sp. tritici in the United States in 2000. 
identified in California in 1998 (Table 4). In 2000, these two races were detected in Alabama, Arkansas, Colorado, Georgia, Indiana, Montana, Texas, and eastern Washington, in addition to California. Of the 21 new races, 16 were virulent on Express (Table 4). Isolates of these 16 new races were collected from California, the Pacific Northwest (Oregon, Washington, and Idaho), the south-central region (Texas, Louisiana, Alabama, Mississippi, Oklahoma, and Arkansas), the north-central region (Kansas, Indiana, Michigan, South Dakota, North Dakota, and Minnesota), and the eastern region (Virginia). Virulence on Express was detected in all 20 states from which we had collections and accounted for $64.2 \%$ of the total isolates. Among the five new races (PST-61, PST-71, PST-72, PST-74, and PST-75) that were avirulent on Express, PST-61, PST71, and PST-75 were detected in western Washington; PST-72 was detected in California and eastern Washington; and PST-74 was detected in North Dakota and western Washington.

Races virulent on $\mathrm{Yr} 8$ and $\mathrm{Yr}$ 9. The most important discovery of the 2000 race survey was the detection of 13 new races virulent on $\operatorname{Yr} 8, \operatorname{Yr} 9$, or both (Table 4), because all the races identified prior to 2000 were avirulent on $\operatorname{Yr} 8$ and $\operatorname{Yr} 9$. These races were detected in California, the $\mathrm{Pa}$ cific Northwest (Washington), the southcentral region (Texas, Louisiana, and Arkansas), the north-central region (Indiana, South Dakota, North Dakota, Minnesota, and Michigan), and the eastern region (Virginia). Among eight new races (PST68, and PST-74 to PST-80) that were virulent on $\mathrm{Yr} 8$, three (PST-68, PST-74, and PST-75) were virulent on the $\operatorname{Yr} 8$ nearisogenic line but not on Compair ( $Y r 8$ and Yr19); and the other five (PST-76 to PST80) were virulent on both the $\operatorname{Yr} 8$ line and Compair. Among 12 new races (PST-69 to
PST-80) that were virulent on $\operatorname{Yr} 9$, only PST-69 and PST-70 were avirulent on Clement $(\mathrm{Yr} 9$ and $\mathrm{YrClem})$; and the other 10 races were virulent on both the $\operatorname{Yr} 9$ line and Clement. The races virulent on $\mathrm{Yr} 8$, $\operatorname{Yr} 9$, or both accounted for $33.4 \%$ of the total isolates.

Frequencies of virulences and associations of the virulences on Express, $\mathrm{Yr} 8$, and $Y r 9$. The frequency of virulence to the differential cultivar Lemhi was $97.5 \%$, followed by Fielder $(88.1 \%)$, Express $(62.3 \%)$, Lee $(54.1 \%)$, and Produra $(45.9 \%)$ (Table 5). The five virulences were all to spring wheat differential cultivars. All top five virulences were detected in all 20 states from which we obtained isolates.

In all, 22 races, which accounted for $72.1 \%$ of the isolates, were virulent on one or more of the differentials Express, $\mathrm{Yr} 8$, and $\operatorname{Yr} 9$ (Table 6). Based on virulence to Express and the near-isogenic lines $\mathrm{Yr} 8$ and $\operatorname{Yr} 9$, these 22 races can be theoretically categorized into seven groups, but six groups were actually detected. Group 1 consisted of nine races that were virulent on Express but not on the $\mathrm{Yr} 8$ and $\mathrm{Yr} 9$ lines. This group had the highest frequency and was found in 14 states. We did not detect any race in group 2 (virulent on the $\operatorname{Yr} 8$ line, but not on Express and the $\operatorname{Yr} 9$ line). Two races were detected for group 3 (virulent on $\operatorname{Yr} 9$, but not on Express and $Y r 8)$. Races in this group were detected only in California and Washington. Only one race (PST-68) was in group 4 (virulent on Express and $\operatorname{Yr} 8$ but not on $\operatorname{Yr} 9$ ), which was detected in California and Indiana. Group 5 consisted of three races that were virulent on Express and $\operatorname{Yr} 9$, but not on Yr8. Races in group 5 were detected in California, Washington, and Michigan. Only two races were detected in group 6 that were virulent on $\mathrm{Yr} 8$ and $\mathrm{Yr} 9$, but not on Express. These races were detected in Washington. Group 7 consisted of five

Table 3. Number of collections of wheat stripe rust and PST races of Puccinia striiformis $\mathrm{f}$. sp. tritici identified in the United States in 2000

\begin{tabular}{lcl}
\hline State & No. of samples & \multicolumn{1}{c}{ PST races } \\
\hline Alabama & 6 & $58,60,63$ \\
Arkansas & 9 & $59,77,78,79,80$ \\
California & 38 & $1,6,58,59,60,63,62,64,65,66,67,68,72,73,78,80$ \\
Colorado & 1 & 59 \\
Georgia & 1 & 58 \\
Idaho & 9 & $14,20,21,26,53,65$ \\
Indiana & 7 & $58,59,68$ \\
Kansas & 6 & 63,78 \\
Louisiana & 3 & 78,80 \\
Michigan & 1 & 60,70 \\
Minnesota & 1 & 76 \\
Mississippi & 3 & 64 \\
Montana & 3 & 58 \\
North Dakota & 8 & $74,78,80$ \\
Oklahoma & 2 & 64 \\
Oregon & 1 & 60 \\
South Dakota & 8 & 79 \\
Texas & 10 & $35,58,59,64,67,78,80$ \\
Virginia & 2 & 80 \\
Washington & 56 & $3,8,11,14,18,20,23,25,29,30,32,35,51,52,53,58$, \\
& & $59,61,65,69,71,72,73,74,75$ \\
\hline
\end{tabular}

races that were virulent on Express, $\operatorname{Yr} 8$, and $Y r 9$. This group had the second highest frequency among the seven possible groups and was detected in California, the southcentral region (Texas, Louisiana, and Arkansas), the north-central region (South Dakota, North Dakota, and Minnesota), and the eastern region (Virginia) but not in the Pacific Northwest. The results indicated that virulences on Express, $\operatorname{Yr} 8$, and $\operatorname{Yr} 9$ were associated.

\section{DISCUSSION}

The distribution of stripe rust in 2000 was the most widespread in recorded history in the United States. Before 2000, the most widespread epidemics of wheat stripe rust had occurred in 1957 and 1958, when stripe rust was recorded in Texas (23), Oklahoma (59), Kansas $(44,45)$, Colorado (37), Wyoming (5), Nebraska (20), South Dakota (27), North Dakota (24), Minnesota (42), and Washington (22). It was not found in Arkansas (47), Missouri (57), Iowa (6), or Manitoba, Canada (25) in 1958. In 2000, wheat stripe rust occurred in at least 20 states throughout the United States. In addition to the states that had stripe rust in 1958, the rust occurred in California, Oregon, Idaho, Montana, Louisiana, Alabama, Mississippi, Arkansas, Missouri, Illinois, Michigan, Virginia, and Georgia. As in the 1958 epidemic, severe and widespread stripe rust in 2000 was partially due to environmental conditions. The mild winter of 1999-2000 in the south-central states was favorable for stripe rust over-wintering, and the cool, wet spring was favorable for rust development and spread. A group of the new races identified in this study was also responsible for the 2000 epidemics.

There had been no race identification research for stripe rust in states east of the Rocky Mountains before 1960. Since the 1960s, stripe rust races east of the Rocky Mountains were few and stable compared with other regions. Therefore, the large region east of the Rocky Mountains, mainly the south-central states, has been considered as a single epidemic region, region 7 (36). Only races PST-3 and PST- 8 were detected in region 7 from the 1960 s to $1997(35,36)$. In 1998 and 1999, two more races (PST-22 and PST-26), similar to PST-3 and PST-8 with additional virulence to Fielder, were detected in the region. The simple and stable race composition could be due to lack of host selection, because wheat breeding programs in that region generally have not been concerned about resistance to stripe rust, and stripe rust had occurred less frequently. In 2000, the race composition in the region became more complicated. Of the 16 races identified from collections in the region, 13 were new in 2000. The stripe rust collections from the states east of the Rocky Mountains were similar in virulence to the collections from California. 
Of the 21 new races, 7 (PST-69, PST-70, PST-72, PST-73, PST-76, PST-77, and PST-78) were identified by adding Compair, Clement, and the $\operatorname{Yr} 8$ and $\operatorname{Yr} 9$ single gene lines to the differential cultivars. Without these additions, races PST-69, PST-70, PST-72, PST-73, PST-76, PST-77, and PST-78 would have been identified as PST-64, PST-59, PST-20, PST-67, PST-62, PST-58, and PST-59, respectively. Because the latter races also were detected in 2000 using the same set of differentials, they were clearly different from the former races. When first identified in 1998, PST58 and PST-59 were used to test $10 \mathrm{Yr}$ near-isogenic lines that were developed in the Plant Breeding Institute in the University of Sydney, Australia. The $\operatorname{Yr} 8$ and $Y r 9$ lines were resistant to PST-58 and PST-59 (X. M. Chen, unpublished data). Most of the races virulent on $\operatorname{Yr} 8$ and $\operatorname{Yr} 9$ identified in 2000 have the virulence of PST-58 or PST-59 plus virulence on $\mathrm{Yr} 8$ and $\mathrm{Yr} 9$.

The resistance gene $\operatorname{Yr} 9$ in wheat, which was transferred from rye through the $1 B / 1 R$ chromosomal substitution and the 1RS/1BL translocation (60) and named by Macer (38), has been widely used in wheat breeding programs in the world $(3,31,32,40,48,60)$. Races of stripe rust with $\operatorname{Yr} 9$ virulence were identified for the first time in the former Soviet Union in 1973, in the Netherlands in 1974 (50), in China in 1977 (54), in East Africa (Ethiopia and Kenya) in 1986 (48), in the Middle East (Syria and Lebanon) in 1989 (26), in South America (Ecuador, Colombia, Ecuador, Bolivia, and Chile) and Mexico in 1988 (51), and in Australasia in 1991 (56). In 1992, 1994, and 1996, the $\operatorname{Yr} 9$ virulence was reported in Iran, Pakistan, and
India, respectively $(43,48)$. Unconfirmed reports of $\mathrm{Yr} 9$ virulence were also received from Afghanistan during this period (48). In addition, the $\operatorname{Yr} 9$ virulence also has been reported in Israel, Tanzania, Rwanda, Zambia, and Turkey $(21,39,51)$. In the United States, the $\operatorname{Yr} 9$ virulence had not been detected until 2000. Wheat cvs. Aurora, Clement, Kavkaz, and Riebesel 47/51 that have $\operatorname{Yr} 9$ (40) had been free of stripe rust in nurseries in California and the Pacific Northwest before 2000. In the United States, $\operatorname{Yr} 9$ has not been widely used in commercial wheat cultivars in major stripe rust epidemic areas such as the Pacific Northwest. East of the Rocky Mountains, sources of $\operatorname{Yr} 9$ were used primarily for leaf rust $(L r 26)$, stem rust (Sr31), and powdery mildew (Pm8) resistance genes that are tightly linked to $\operatorname{Yr} 9$ (40).

Table 4. Races of Puccinia striiformis f. sp. tritici (PST), their virulence formula, first year of detection, prevalence in 2000, and distribution prior to 2000 and in 2000 in the United States

\begin{tabular}{|c|c|c|c|c|c|}
\hline \multirow[b]{2}{*}{ PST race } & \multirow[b]{2}{*}{ Virulence formula } & \multirow[b]{2}{*}{ First detected $^{\text {b }}$} & \multirow[b]{2}{*}{ Detected in $2000(\%)$} & \multicolumn{2}{|c|}{ Distribution in epidemic regions (states) ${ }^{\mathrm{a}}$} \\
\hline & & & & Before 2000 & In 2000 \\
\hline 1 & 1,2 & Before 1963 & 0.6 & $1,2,4,5,6$ & $6(\mathrm{CA})$ \\
\hline 3 & 1,3 & Before 1963 & 0.6 & $1,2,3,4,5,6,7$ & 1 (E-WA) \\
\hline 6 & $1,6,8,12$ & 1972 & 0.6 & $1,2,3,4,5,6$ & $6(\mathrm{CA})$ \\
\hline 11 & 1 & 1976 & 1.9 & 5,6 & 5 (W-WA) \\
\hline 14 & $1,8,12$ & 1976 & 1.9 & 1,6 & 1 (E-WA, ID), 5 (W-WA) \\
\hline 18 & $1,3,4,9$ & 1977 & 0.6 & 1,5 & 1 (E-WA) \\
\hline 19 & $1,3,6,8,10,12$ & 1977 & 0.6 & $1,2,3,4,5,6$ & 5 (W-WA) \\
\hline 20 & $1,6,8,10,12$ & 1977 & 11.3 & $1,2,3,4,5,6$ & 1 (E-WA, ID), 5 (W-WA), \\
\hline 21 & 2 & 1978 & 2.5 & 6 & 1 (ID) \\
\hline 23 & $1,3,6,9,10$ & 1981 & 0.6 & 5 & 1 (E-WA) \\
\hline 25 & $1,3,6,8,9,10,12$ & 1981 & 0.6 & $1,4,5$ & 1 (E-WA) \\
\hline 26 & $1,3,9,12$ & 1982 & 0.6 & $1,4,5$ & 1 (ID) \\
\hline 29 & $1,3,4,5$ & 1983 & 2.5 & 1 & 1 (E-WA, ID) \\
\hline 30 & $1,4,6,8,12$ & 1983 & 1.9 & 1 & 5 (W-WA) \\
\hline 32 & 1,4 & 1983 & 1.9 & 1 & 5 (W-WA) \\
\hline 35 & 1,10 & 1985 & 3.1 & 6 & 1 (E-WA), 5 (W-WA), 6 (CA), 7 (TX) \\
\hline 51 & $1,3,4,12,14$ & 1992 & 0.6 & 1 & 1 (E-WA) \\
\hline 52 & $1,4,8,12,14$ & 1993 & 0.6 & 1 & 1 (E-WA) \\
\hline 53 & $1,6,10$ & 1994 & 1.9 & 5 & 1 (ID), 5(W-WA) \\
\hline 58 & $1,11,12,16$ & 1998 & 10.7 & 6 & 1 (E-WA), 6 (CA), 7 (AL, AR, GA, IN, MT, TX) \\
\hline 59 & $1,3,11,12,16$ & 1998 & 11.2 & 6 & 1 (E-WA), 6 (CA), 7 (AR, CO, IN, MT, TX) \\
\hline 60 & $1,12,16$ & 2000 & 3.1 & NA & 4 (OR ), 6 (CA), 7 (AL, MI) \\
\hline 61 & $1,4,10,12$ & 2000 & 0.6 & NA & 5 (W-WA) \\
\hline 62 & $1,2,12,16$ & 2000 & 0.6 & NA & $6(\mathrm{CA})$ \\
\hline 63 & $1,8,12,16$ & 2000 & 1.3 & NA & 7 (AL, KS) \\
\hline 64 & $1,2,11,12,16$ & 2000 & 5.7 & NA & 6 (CA), 7 (MS, OK, TX) \\
\hline 65 & $1,8,10,12,16$ & 2000 & 2.5 & NA & 1 (ID), 5 (W-WA), 6(CA) \\
\hline 66 & $1,2,10,11,12,16$ & 2000 & 1.3 & NA & $6(\mathrm{CA}), 7(\mathrm{TX})$ \\
\hline 67 & $1,2,3,11,12,16$ & 2000 & 1.9 & NA & 6 (CA), 7 (TX) \\
\hline 68 & $1,3,12,16,17$ & 2000 & 1.3 & NA & $6(\mathrm{CA}), 7(\mathrm{IN})$ \\
\hline 69 & $1,2,11,12,16,18$ & 2000 & 1.3 & NA & 5 (W-WA) \\
\hline 70 & $1,3,11,12,16,18$ & 2000 & 0.6 & NA & 7 (MI) \\
\hline 71 & $1,8,10,12,18,19$ & 2000 & 1.9 & NA & 5 (W-WA) \\
\hline 72 & $1,6,8,10,12,18,19$ & 2000 & 1.3 & NA & 1 (E-WA), 6 (CA) \\
\hline 73 & $1,2,3,11,12,16,18,19$ & 2000 & 1.3 & NA & 1 (E-WA), 6 (CA) \\
\hline 74 & $1,8,10,12,17,18,19$ & 2000 & 3.1 & NA & 5 (W-WA), 7 (ND) \\
\hline 75 & $1,4,8,10,12,17,18,19$ & 2000 & 0.6 & NA & $5(\mathrm{~W}-\mathrm{WA})$ \\
\hline 76 & $1,2,12,16,17,18,20$ & 2000 & 0.6 & NA & $7(\mathrm{MN})$ \\
\hline 77 & $1,11,12,16,17,18,19,20$ & 2000 & 0.6 & NA & 7 (AR) \\
\hline 78 & $1,3,11,12,16,17,18,19,20$ & 2000 & 7.6 & NA & 6 (CA), 7 (AR, KS, LA, ND, TX) \\
\hline 79 & $1,8,11,12,16,17,18,19,20$ & 2000 & 1.3 & NA & $7(\mathrm{AR}, \mathrm{SD})$ \\
\hline 80 & $1,3,8,11,12,16,17,18,19,20$ & 2000 & 12.0 & NA & 6 (CA), 7 (AR, LA, ND, TX, VA) \\
\hline
\end{tabular}

a Epidemic regions of stripe rust in North America: 1 = region 1, including eastern Washington, northeastern Oregon, northern Idaho, southeastern British Columbia, and southwestern Alberta; 2 = region 2, including western Montana, southeastern Alberta, and southwestern Saskatchewan; $3=$ region 3 , including southeastern Oregon, southern Idaho, northern Nevada, northern Utah, and western Colorado; $4=$ region 4 , including western Oregon and northern California; $5=$ western Washington and southwestern British Columbia; $6=$ region 6 , including central California; and $7=$ region 7 , including all areas east of the Rocky Mountains (36). NA = not applicable.

${ }^{\mathrm{b}}$ Line and Chen (35) 
The gene $\operatorname{Yr} 8$ was introduced into wheat from Aegilops comosa by genetically induced homoeologous recombination (46). The gene has been used less intensively in breeding programs than $\mathrm{Yr} 9$. It is not clear whether $\operatorname{Yr} 8$ is present in commercial cultivars that have been grown in recent years in the United States. Similarly, the gene $\mathrm{Sr} 34$ from A. comosa in Compair for resistance to stem rust has not been used in commercial cultivars because the Sr34 virulence is common (41). The virulence to $\mathrm{Yr} 8$ was detected in the Middle East in 1973 (26), in England in 1978 (33), in Australia in 1980s (55), and in Iran during
1997 to 1999 (43). Many of the isolates detected in 2000 in the United States that were virulent to $\operatorname{Yr} 8$ were also virulent to $\operatorname{Yr} 9$ and Express.

A high percentage of widely distributed isolates in 2000 had the combination of virulences to Express, $\operatorname{Yr} 8$, and $\operatorname{Yr} 9$. It is not clear how these virulences evolved in the similar isolates. Stripe rust isolates with virulence factors on $\operatorname{Yr} 8$ and $\operatorname{Yr} 9$ were detected in Ethiopia in 1987 (2). The virulence to Express was first detected in California in 1997 (R. F. Line and X. M. Chen, unpublished data) and the $\operatorname{Yr} 9$ virulence has been in Mexico for many years (51; R.
Singh, personal communication). The considerable number of different races involving virulences on Express, $\mathrm{Yr} 8$, and $\mathrm{Yr} 9$ suggests that the combination of these virulences might have occurred through somatic recombination or mutation between 1997 and 2000. Somatic recombination plays a major role in variation of stripe rust populations and formation of new races with combinations of previously existing virulences $(17,18,52,58)$. In California, all virulences detected in 2000, except for $\operatorname{Yr} 8$ and $\operatorname{Yr} 9$, were previously detected. These virulences include those on Lemhi, Chinese 166, Druchamp, Produra,

Table 5. Virulence factors of Puccinia striiformis f. sp. tritici on differential cultivars and their percentages in collections and distributions in the United States in 2000

\begin{tabular}{|c|c|c|}
\hline Virulence on differential (gene) ${ }^{\mathbf{a}}$ & Percentage $(\%)$ & Distribution in epidemic regions (states) ${ }^{\mathbf{b}}$ \\
\hline Lemhi $(Y r 21)$ & 97.5 & $\begin{array}{l}1 \text { (E-WA, ID), } 4 \text { (OR), } 5 \text { (W-WA), } 6 \text { (CA), } 7 \text { (AL, AR, CO, GA, IN, KS, LA, MI, MN, MS, } \\
\text { MT, ND, OK, SD, TX, VA) }\end{array}$ \\
\hline Chinese $166(Y r I)$ & 15.1 & 1 (ID), 5 (W-WA), 6 (CA), 7 (MN, MS, OK, TX) \\
\hline Heines VII $(Y r 2, Y r H V I I)$ & 39.6 & 1 (E-WA, ID), 5(W-WA), 6(CA), 7(AR, CO, IN, MI, ND, LA, TX, VA) \\
\hline Moro (Yr10, YrMor) & 8.8 & 1 (E-WA), 5 (W-WA) \\
\hline Paha $(\mathrm{YrPa1}, \mathrm{YrPa}, \mathrm{YrPa} 3)$ & 2.5 & 1 (E-WA) \\
\hline Druchamp (Yr3a, YrD, YrDru) & 18.9 & 1 (E-WA, ID), 5 (W-WA), 6 (CA) \\
\hline Riebesel 47/51 $(\operatorname{Yr} 9,+)$ & $0.0^{\mathrm{c}}$ & $\ldots$ \\
\hline Produra $(Y r P r 1, Y r P r 2)$ & 45.9 & 1 (E-WA, ID), 5 (W-WA), 6 (CA), 7 (AL, AR, KS, LA, ND, SD, TX, VA) \\
\hline Yamhill $(\mathrm{Yr} 2, \mathrm{Yr} 4 a, \mathrm{YrYam})$ & 5.7 & 1 (E-WA, ID), 5 (W-WA) \\
\hline Stephens $(Y r 3 a, Y r S, Y r S t e)$ & 32.1 & 1 (E-WA, ID), 5 (W-WA), 6 (CA), 7 (AR, ND, TX) \\
\hline Lee $(Y r 7, Y r 22, Y r 23)$ & 54.1 & $\begin{array}{l}1 \text { (E-WA), } 5 \text { (W-WA), } 6 \text { (CA), } 7 \text { (AL, AR, CO, GA, IN, LA, MI, MS, MT, ND, OK, SD, } \\
\text { TX, VA) }\end{array}$ \\
\hline Fielder (Yr6, YrFie $)$ & 88.1 & $\begin{array}{l}1 \text { (E-WA, ID), } 5 \text { (W-WA), } 6 \text { (CA), } 7 \text { (AL, AR, CO, IN, KS, LA, MI, MS, MT, ND, OK, } \\
\text { OR, SD, TX, VA) }\end{array}$ \\
\hline Tyee (YrTye) & 0.0 & .. \\
\hline Tres $(\operatorname{YrTr} 1, \operatorname{YrTr} 2)$ & 1.9 & 1 (E-WA), 5 (W-WA) \\
\hline Hyak $(\operatorname{Yr} 17+?)$ & 0.0 & \\
\hline Express (unknown) & 62.3 & $\begin{array}{l}1 \text { (E-WA, ID), } 4 \text { (OR), } 5 \text { (W-WA), } 6 \text { (CA), } 7 \text { (AL, AR, CO, GA, IN, KS, LA, MI, MN, MS, } \\
\text { MT, ND, OK, SD, TX, VA) }\end{array}$ \\
\hline $\operatorname{Yr8}(\mathrm{Yr} 8)$ & 27.0 & 5 (W-WA), 6 (CA), 7 (AR, IN, LA, MN, ND, SD, VA, TX) \\
\hline Yr9 $(Y r 9)$ & 30.2 & 1 (E-WA), 5 (W-WA), 6 (CA), 7 (AR, LA, MI, MN, ND, SD, TX, VA) \\
\hline Clement $(\mathrm{Yr} 9, \mathrm{YrCle})$ & 28.3 & 1 (E-WA), 5 (W-WA), 6 (CA), 7 (AR, LA, ND, SD, TX, VA) \\
\hline Compare $(\operatorname{Yr} 8, \operatorname{Yr} 19)$ & 20.8 & 6 (CA), 7 (AR, LA, MN, ND, SD, TX, VA) \\
\hline
\end{tabular}

${ }^{\mathrm{a}}$ Chen and Line (9-12), Chen et al. (8,15,16), and McIntosh et al. (40).

${ }^{\mathrm{b}}$ Epidemic regions of stripe rust in North America: 1 = region 1, including eastern Washington, northeastern Oregon, northern Idaho, southeastern British Columbia, and southwestern Alberta; 2 = region 2, including western Montana, southeastern Alberta, and southwestern Saskatchewan; $3=$ region 3 , including southeastern Oregon, southern Idaho, northern Nevada, northern Utah, and western Colorado; $4=$ region 4 , including western Oregon and northern California; $5=$ western Washington and southwestern British Columbia; $6=$ region 6 , including central California; and $7=$ region 7 , including all areas east of the Rocky Mountains (36).

c Although none of the 2000 isolates produced susceptible reactions (infection types 7, 8, and 9), some isolates produced urediniospores on Riebesel 47/51 (infection types 3 to 5).

Table 6. Associations of virulences to Express and the $\operatorname{Yr} 8$ and $\operatorname{Yr} 9$ near-isogenic lines in races of Puccinia striiformis f. sp. tritici in the United States in 2000

\begin{tabular}{|c|c|c|c|c|}
\hline Race group & $\begin{array}{l}\text { No. of } \\
\text { races }\end{array}$ & PST races & $\begin{array}{l}\text { Percentage of } \\
\text { isolates }(\%)^{\mathrm{a}}\end{array}$ & Distribution in epidemic regions (states) ${ }^{\mathbf{b}}$ \\
\hline 1. Races virulent on Express but not on $\mathrm{Yr} 8$ and $\mathrm{Yr} 9$ & 9 & $\begin{array}{l}58,59,60,62,63 \\
64,65,66,67\end{array}$ & $38.4(53.5)$ & $\begin{array}{c}1 \text { (E-WA, ID), } 5 \text { (W-WA), } 6 \text { (CA), } 7 \text { (AL, AR, } \\
\text { GA, IN, KS, MI, MS, MT, OK, OR, TX) }\end{array}$ \\
\hline 2. Races virulent on $Y r 8$ but not on Express and $Y r 9$ & 0 & $\ldots$ & $0(0)$ & $\ldots$ \\
\hline 3. Races virulent on $\operatorname{Yr} 9$ but not on Express and $\operatorname{Yr} 8$ & 2 & 71,72 & $3.2(4.4)$ & 1 (E-WA), 5 (W-WA), 6 (CA) \\
\hline 4. Races virulent on Express and $Y r 8$ but not on $Y r 9$ & 1 & 68 & $1.3(1.8)$ & 6 (CA), 7 (IN) \\
\hline 5. Races virulent on Express and $Y r 9$ but not on $Y r 8$ & 3 & $69,70,73$ & $3.2(4.4)$ & 1 (E-WA), 5 (W-WA), 6 (CA), 7 (MI) \\
\hline 6. Races virulent on $\operatorname{Yr} 8$ and $\operatorname{Yr} 9$ but not on Express & 2 & 74,75 & $3.8(5.3)$ & 5 (W-WA) \\
\hline 7. Races virulent on Express, $Y r 8$, and $Y r 9$ & 5 & $76,77,78,79,80$ & $22.0(30.7)$ & 6 (CA), 7 (AR, LA, MN, ND, SD, TX, VA) \\
\hline Total & 22 & ? & $72.1(100.0)$ & $\ldots$ \\
\hline
\end{tabular}

${ }^{\text {a }}$ The first value is the percentage of the group isolates calculated based on all tested isolates and the value in parentheses is the percentage of the group isolates calculated based on isolates virulent on Express, $\operatorname{Yr} 8$, and/or $\operatorname{Yr} 9$.

${ }^{\mathrm{b}}$ The epidemic regions of stripe rust in North America: 1 = region 1, including eastern Washington, northeastern Oregon, northern Idaho, southeastern British Columbia, and southwestern Alberta; 2 = region 2, including western Montana, southeastern Alberta, and southwestern Saskatchewan; $3=$ region 3 , including southeastern Oregon, southern Idaho, northern Nevada, northern Utah, and western Colorado; $4=$ region 4 , including western Oregon and northern California; $5=$ western Washington and southwestern British Columbia; $6=$ region 6 , including central California; and $7=$ region 7 , including all areas east of the Rocky Mountains (36). 
Stephens, Lee, Fielder, and Express. Many of the new races detected in California in 2000 can be considered to result from the addition of virulence factors on $\mathrm{Yr} 8$ and $\operatorname{Yr} 9$ to previously existing races. For example, race PST-78 has the virulence factors of PST-59 plus those on $\operatorname{Yr} 8, \operatorname{Yr} 9$, Clement, and Compair; and race PST-72 has the virulence factors of PST-20 plus those on $\operatorname{Yr} 8$ and $\operatorname{Yr} 9$.

The origin of inoculum of stripe rust for the 2000 epidemics in the south-central, north-central, and eastern states is unknown. We could speculate that the initial inoculum might be from Mexico as in the epidemics in Kansas in $1958(23,44)$. The speculation is supported by the fact that $\operatorname{Yr} 9$ virulence has been in Mexico for many years $(51$; R. Singh, personal communication). Most of the isolates from Arkansas, Texas, Louisiana, and other states, however, were also virulent on $\operatorname{Yr} 8$ and Express, in addition to $\operatorname{Yr} 9$. If the inoculum in these areas was from Mexico, the stripe rust population in Mexico should also be virulent on $\operatorname{Yr} 8$ and Express, in addition to Yr9. However, according to R. Singh (personal communication), the $\operatorname{Yr} 9$-virulent isolates in Mexico are not virulent on the $\operatorname{Yr} 8$ near-isogenic line, which was used in this study as a differential, and the cultivar Express has not been grown in Mexico. The gene or genes in Express for stripe rust resistance are not known. It is possible that the same gene or genes in Express might have been used in the Mexican wheat breeding programs. It also is possible that the inoculum for the stripe rust epidemic in the south-central states and other states in the Great Plains might be from California. Most collections from the states east of the Rocky Mountains were races PST-58 and PST-59 plus the virulence on $\operatorname{Yr} 9$ and $\operatorname{Yr} 8$. PST-58 and PST-59, the first two races virulent on Express, were first identified in California in 1998 and might have been present in 1997 (R. F. Line and X. M. Chen, unpublished data). It is conceivable that the recombination or mutation of Express-virulence and $\operatorname{Yr} 9$-virulence occurred in California and spread to the regions east of the Rocky Mountains before 2000. All these hypotheses can be tested by further studies including Mexican isolates using a combination of virulence tests and molecular techniques. The present study and further studies may lead to redetermination of stripe rust epidemic regions and better understanding of longdistance dissemination, over-wintering, and over-summering of the pathogen in different regions.

The appearance of the new races with virulence on $\operatorname{Yr} 8, \operatorname{Yr} 9$, and Express in the United States may be a problem in California and states east of the Rocky Mountains, but not an immediate problem for the Pacific Northwest, because the major wheat cultivars in the Pacific Northwest have non-race-specific, high-temperature, adult-plant resistance $(13,14,19,34)$ that has not been largely used in California and states east of the Rocky Mountains. For the club wheat cultivars, in which genes for race-specific resistance to stripe rust have been widely used, multiline cultivars, such as 'Rely', with many single genes in its components, have been used to control stripe rust (1). For California and the central and south-central states, such as Kansas, Oklahoma, Arkansas, Texas, and Louisiana, combinations of genes for stripe rust resistance may be used in breeding new cultivars with stripe rust resistance. Fungicide applications in the central and south-central states can reduce yield losses, and the benefits from fungicide applications can be maximized by accurately forecasting stripe rust epidemics in these regions.

\section{ACKNOWLEDGMENTS}

We thank the Washington Wheat Commission for partial financial support for this project; B. Bowden of Kansas State University, B. Brown of Colorado State University, B. Brown of University of Idaho, C. Griffey of the Virginia Tech., S. Harrison of Louisiana State University, R. M. Hunger of Oklahoma State University, Y. Jin of South Dakota State University, R. Karow of Oregon State University, and others for sending stripe rust collections; and F. Dugan, T. Peever, and the two anonymous reviewers for their critical review of the manuscript.

\section{LITERATURE CITED}

1. Allan, R. E., Peterson, C. J., Line, R. F., Rubenthaler, G. L., and Morris, C. F. 1993. Registration of 'Rely' wheat multiline. Crop Sci. 33:213-214.

2. Badebo, A., Stubbs, R. W., Ginkel, M. V., and Gebeyehu, G. 1990. Identification of resistance genes to Puccinia striiformis in seedlings of Ethiopian and CIMMYT bread wheat. Neth. J. Plant Pathol. 96:199-210.

3. Bartos, P., Valkoun, J., Kosner, J., and Slovencikova, V. 1973. Rust resistance of some European wheat cultivars derived from rye. Pages 145-146 in: Proc. 4th Int. Wheat Genetics Symp. Columbia, MO.

4. Bever, W. W. 1934. Physiologic specialization in Puccinia glumerum in the United States. Phytopathology 24:686-688.

5. Bridgmon, G. H., and Kolp, B. J. 1959. Stripe rust in Wyoming in 1958. Plant Dis. Rep. 43:163-164.

6. Browning, J. A. 1959. Short notes concerning stripe rust in other states: Iowa. Plant Dis. Rep. 43:172.

7. Carleton, M. A. 1915. A serious new wheat rust in this country. Science 42:58-59.

8. Chen, X. M., Jones, S. S., and Line, R. F. 1996. Chromosomal location of genes for resistance to Puccinia striiformis in seven wheat cultivars having resistance genes at $Y r 3$ and $Y r 4$ loci. Phytopathology 86:1228-1233.

9. Chen, X. M., and Line, R. F. 1992. Inheritance of stripe rust resistance in wheat cultivars used to differentiate races of Puccinia striiformis in North America. Phytopathology 82:633-637.

10. Chen, X. M., and Line, R. F. 1992. Identification of stripe rust resistance genes in wheat cultivars used to differentiate North American races of Puccinia striiformis. Phytopathology 82:1428-1434.

11. Chen, X. M., and Line, R. F. 1992. Genes for resistance to stripe rust in 'Tres' wheat. Crop Sci. 32:692-696.
12. Chen, X. M., and Line, R. F. 1993 Inheritance of stripe rust resistance in wheat cultivars postulated to have resistance genes at $Y r 3$ and $Y r 4$ loci. Phytopathology 83:382388.

13. Chen, X. M., and Line, R. F. 1995. Gene action in wheat cultivars for durable high-temperature adult-plant resistance and interactions with race-specific, seedling resistance to stripe rust caused by Puccinia striiformis. Phytopathology 85:567-572.

14. Chen, X. M., and Line, R. F. 1995. Gene number and heritability of wheat cultivars with durable, high-temperature, adult-plant resistance and race-specific resistance to Puccinia striiformis. Phytopathology 85:573578.

15. Chen, X. M., Line, R. F. and Jones, S. S. 1995. Chromosomal location of genes for stripe rust in spring wheat cultivars Compair, Fielder, Lee, and Lemhi and interactions of anueploid wheats with races of Puccinia striiformis. Phytopathology 85:375-381.

16. Chen, X. M., Line, R. F. and Jones, S. S. 1995. Chromosomal location of genes for resistance to Puccinia striiformis in winter wheat cultivars Heines VII, Clement, Moro, Tyee, Tres, and Daws. Phytopathology 85:1362-1367.

17. Chen, X. M., Line, R. F., and Leung, H. 1993. Relationship between virulence variation and DNA polymorphism in Puccinia striiformis. Phytopathology 83:1489-1497.

18. Chen, X. M., Line, R. F., and Leung, H. 1995. Virulence and polymorphic DNA relationships of Puccinia striiformis f. sp. hordei to other rusts. Phytopathology 85:1335-1342.

19. Chen, X. M., Line, R. F., Shi, Z. X., and Leung, H. 1998. Genetics of wheat resistance to stripe rust. Pages 237-239 in: Proc. 9th Int. Wheat Genet. Symp. Vol. 3. Saskatoon, Canada.

20. Daly, J. M. 1957. Short notes concerning stripe rust in other states: Nebraska. Plant Dis. Rep. 41:962.

21. Düsünceli, F., Cetin, L., Albustan, S., and Beniwal, S. P. S. 1996. Occurrence and impact of wheat stripe rust (Puccinia striiformis) in Turkey in 1994/95 crop season. Proc. Eur. Mediterr. Cereal Rusts Powdery Mildew Conf. 9:309.

22. Fischer, G. W. 1959. Short notes concerning stripe rust in other states: Washington. Plant Dis. Rep. 43:172.

23. Futrell, M. C., Atkins, I. M., and Hobbs, C. D. 1959. Unusual occurrence of small-grain diseases in Texas in 1957 and 1958. Plant Dis. Rep. 43:777-781.

24. Gough, F. J., Williams, N. D., and Brentzel, W. E. 1959. Occurrence of stripe rust in North Dakota in 1958. Plant Dis. Rep. 169-171.

25. Green, G. J. 1959. Short notes concerning stripe rust in other states: Manitoba, Canada Plant Dis. Rep. 43:172.

26. Hakim, M. S., and Mamluk, O. F. 1996. Virulence of wheat yellow rust pathogen in Syria and Lebanon. Proc. Eur. Mediterr. Cereal Rusts Powdery Mildew Conf. 9:141.

27. Hennen, J. F., and Komanetsky, M. 1959. Stripe rust in South Dakota in 1958. Plant Dis. Rep. 43:168-169

28. Humphrey, H. B., Hungerford, C. W., and Johnson, A. G. 1924. Stripe rust (Puccinia glumarum) of cereals and grasses in the United States. J. Agric. Res. 29:209-227.

29. Hungerford, C. W. 1923. Studies on the life history of stripe rust (Puccinia glumerum (Schm.) Eriks. and Henn.). J. Agric. Res. 24:607-620.

30. Hungerford, C. W., and Owens, C. E. 1923. Specialized varieties of Puccinia glumerum and hosts for variety tritici. J. Agric. Res. 
25:363-401.

31. Jing, J. X., Shang, H. S., and Li, Z. Q. 1992. The resistance of important wheat accessions and candidate cultivars to mutants of stripe rust races. Acta Univ. Agric. BorealiOccidentalis 23:7-11.

32. Johnson, R., and Bimb, H. P. 1996. Genetics of resistance to yellow rust in CIMMYT wheats. Proc. Eur. Mediterr. Cereal Rusts Powdery Mildew Conf. 9:195-197.

33. Johnson R., Priesley, R. H., and Taylor, E. C. 1978. Occurrence of virulence in Puccinia striiformis for Compair wheat in England. Cereal Rusts Bull. 3:4-6.

34. Line, R. F., and Chen, X. M. 1995. Successes in breeding for and managing durable resistance to wheat rusts. Plant Dis. 79:1254-1255.

35. Line, R. F., and Chen, X. M. 1996. Wheat and barley stripe rust in North America. Proc. Eur. Mediterr. Cereal Rusts Powdery Mildew Conf. 9:101-104.

36. Line, R. F., and Qayoum, A. 1991. Virulence, aggressiveness, evolution, and distribution of races of Puccinia striiformis (the cause of stripe rust of wheat) in North America, 196887. USDA-ARS Tech. Bull. 1788.

37. Lungren, E. A. 1957. Short notes concerning stripe rust in other states: Colorado. Plant Dis. Rep. 41:962.

38. Macer, R. C. F. 1975. Plant pathology in a changing world. Trans. Br. Mycol. Soc. 65:351-374.

39. Manisterski, J., Kosman, E., and Eyal, Z. 1996. Changes in wheat leaf rust and yellow rust populations in Israel. Proc. Eur. Mediterr. Cereal Rusts Powdery Mildew Conf. 9:140.

40. McIntosh, R. A., Hart, G. E., Devos, K. M., Gale, M. D., and Rogers, W. J. 1998. Cata- logue of gene symbols for wheat. Pages 123172 in: Proc. 9th Int. Wheat Genet. Symp. Univ. Saskatchewan, Saskatoon, Canada.

41. McIntosh, R. A., Wellings, C. R., and Park, R. F. 1995. Wheat Rusts: An Atlas of Resistance Genes. CSIRO, Australia.

42. Miller, J. D., and Christensen, J. J. 1959. Occurrence of stripe rust in Minnesota in 1958. Plant Dis. Rep. 43:159.

43. Nazari K., and Torabi, M. 2000. Distribution of yellow rust $(Y r)$ resistance genes in Iran. Acta Phytopathol. Entomol. Hung. 35:121131.

44. Pady, S. M., and Johston, C. O. 1959. Stripe rust in Kansas in 1958. Plant Dis. Rep. 43:159-163.

45. Pady, S. M., Johnston, C. O., and Rogerson, C. T. 1957. Stripe rust of wheat in Kansas in 1957. Plant Dis. Rep. 41:959-961.

46. Riley, R., Champman, V., and Johnson R. 1968. Introduction of yellow rust resistance of Aegilops comosa into wheat by genetically induced homoeologous recombination. Nature 217:383-384

47. Rosen, H. R. 1959. Short notes concerning stripe rust in other states: Arkansas. Plant Dis. Rep. 43:172.

48. Saari, E. E. 1996. The $\operatorname{Yr} 9$ virulence factor in Puccinia striiformis and South Asia: coevolution or migration from a distant place. Proc. Eur. Mediterr. Cereal Rusts Powdery Mildew Conf. 9:142.

49. Shaner, G., and Powelson, R. L. 1971. Epidemiology of stripe rust of wheat, 19611968. Oreg. Agric. Exp. Stn. Tech. Bull. 117.

50. Stubbs, R. W., Slovencikova, V., and Bartos, P. 1977. Yellow rust resistance of some European wheat cultivars derived from rye. Cereal Rusts Bull. 5:45-47.
51. Stubbs R. W., and Yang, H. A. 1988. Pathogenicity of Puccinia striiformis for wheat cultivars with resistance derived from rye. Proc. Eur. Mediterr. Cereal Rusts Conf. 7:110 112.

52. Taylor, E. C. 1976. The production and behavior of somatic recombinants in Puccinia striiformis. Proc. Eur. Mediterr. Cereal Rusts Conf. 4:36-38

53. Tollenaar, H., and Houston, B. R. 1967. A study on the epidemiology of stripe rust, Puccinia striiformis West., in California. Can. J. Bot. 45:291-307.

54. Wang, K. N., Hong, X. W., Wu, L. R., Xie, S. X., Meng, Q. Y., and Chen, S. M. 1986. The analysis of the resistance of varieties in the wheat stripe rust nurseries in 1951-1983. Acta Phytophylacica Sin. 13:112-123.

55. Wellings, C. R. 1988. Pathotype evolution of Puccinia striiformis f. sp. tritici in Eastern Australia and New Zealand. Proc. Eur. Mediterr. Cereal Rusts Conf. 7:135-136.

56. Wellings, C. R., and Burdon, J. J. 1992. Variability in Puccinia striiformis f. sp. tritici in Australasia. Proc. Eur. Mediterr. Cereal Rusts Powdery Mildews Conf. 8:114.

57. Whitehead, W. D. 1959. Short notes concerning stripe rust in other states: Missouri. Plant Dis. Rep. 43:172.

58. Wright, R. G., and Lennard, J. H. 1980 Origin of a new race of Puccinia striiformis. Trans. Br. Mycol. Soc. 74:283-287.

59. Yong, H. C., and Browder, L. E. 1957. Occurrence of stripe rust in Oklahoma in 1957 Plant Dis. Rep. 41:958-959.

60. Zeller, F. J. 1973. 1B/1R wheat-rye chromosome substitutions and translocations. Pages 209-221 in: Proc. 4th Int. Genet. Symp Columbia, $\mathrm{MO}$ 